\title{
Parking Management and Commuter Rail: The Case of Northeastern Illinois
}

Erik Ferguson, ETF Associates

\begin{abstract}
$\overline{\text { Abstract }}$
This article examines the relationship between parking management and commuter rail transit using the Chicago metropolitan area in northeastern Illinois as a case example. Commuter rail transit and parking management are discussed within the broader context of transportation planning in the Chicago metropolitan region. Commuter rail ridership, mode of station access, and parking utilization rates are compared. Related air quality, social equity, and land-use concerns are reviewed.

There are no simple solutions to the problem of spillover parking around commuter rail stations. The construction of new parking can be expensive. Raising parking prices may induce spillover parking. Doing nothing to address observed parking shortages may inhibit ridership. Shared parking is an excellent compromise in many situations, but even this is far from a universal solution.

\section{Introduction}

There has been a resurgence of interest in commuter rail in the United States recently, with extensive new commuter rail operations starting up in both California and Florida (Gray 1992). Established commuter rail service providers typically experience lower unit costs than do start-up operations. Among established North American commuter rail systems, Chicago's Metra, with operational characteristics midway between New York and New Jersey on the one hand and
\end{abstract}


Philadelphia and Toronto on the other, has the lowest overall unit costs, unit fares, and unit subsidies of any comparable commuter rail service (Table 1).

Despite Metra's admirable efficiency as a transit service provider, it has been criticized for its supposed failures on the equity side on more than one occasion. At one time or another, Metra has been accused of contributing to regional air pollution, failing to serve communities of color, and aiding and abetting in the continuation of long-term trends toward urban sprawl. Each of these charges are addressed in this article.

The issue of additional parking construction to serve Metra rail stations is a good case in point. Metra riders who drive alone to access commuter rail generate more pollution than those who use alternative modes to do so. Metra users are more likely to drive alone to access Metra stations the further they live away from the Chicago central business district (CBD). The more parking is built around commuter rail stations, the less land is available for mixed-use developments and other neo-traditional urban forms. The appropriate solution might seem to be to restrict parking availability around Metra stations in order to encourage alternative modes of station access. The purpose of this article is to demonstrate that the obvious solution is unlikely to provide many tangible benefits, and may, in fact, produce a variety of negative externalities instead.

\section{Transportation Planning}

Regional transportation planning has a long history in Chicago (Black 1990). Many different agencies share this responsibility (Table 2). Agencies involved in highway planning include:

- Chicago Area Transportation Study (CATS),

- Northeastern Illinois Planning Commission (NIPC),

- Regional Council of Mayors, and

- City of Chicago.

Other agencies involved in transit planning include:

- Regional Transportation Authority (RTA),

- Chicago Transit Authority (CTA),

- Metra, and

- Pace. 


\begin{tabular}{|c|c|c|c|c|c|}
\hline \multirow[b]{2}{*}{ Operator } & \multicolumn{4}{|c|}{$\begin{array}{l}\text { Table } 1 \\
\text { Commuter Rail in North America } \\
\text { Top Five Commuter Rail Systems }\end{array}$} & \multirow[b]{2}{*}{ GO Tran } \\
\hline & LIRR & NJT & Metra & SEPTA & \\
\hline Area served & New York & New Jersey & Chicago & Philadelphia & Toronto \\
\hline Line miles & 595 & 569 & 424 & 282 & 245 \\
\hline Annual passengers (millions) & 75.4 & 46.9 & 67.8 & 25.7 & 24.0 \\
\hline Annual passenger-miles (millions) & 2,019 & 1,020 & 1,415 & 357 & 456 \\
\hline Passenger-miles/passenger & 26.8 & 21.7 & 20.9 & 13.9 & 19.0 \\
\hline Annual operating cost (millions) & $\$ 603.1$ & $\$ 279.8$ & $\$ 275.4$ & $\$ 157.9$ & $\$ 179.1$ \\
\hline Annual farebox revenues (millions) & $\$ 266.7$ & $\$ 143.2$ & $\$ 142.8$ & $\$ 61.1$ & $\$ 86.5$ \\
\hline Annual operating subsidy (millions) & $\$ 336.4$ & $\$ 136.6$ & $\$ 132.6$ & $\$ 96.8$ & $\$ 92.6$ \\
\hline Operating cost/passenger-mile & $\$ 0.299$ & $\$ 0.274$ & $\$ 0.195$ & $\$ 0.442$ & $\$ 0.393$ \\
\hline Farebox revenue/passenger-mile & $\$ 0.132$ & $\$ 0.140$ & \$0.101 & $\$ 0.171$ & $\$ 0.190$ \\
\hline Operating subsidy/passenger-mile & $\$ 0.167$ & $\$ 0.134$ & $\$ 0.094$ & $\$ 0.271$ & $\$ 0.203$ \\
\hline
\end{tabular}

Source: Gray (1992). 


\section{Table 2}

\section{Transportation Planning Expenditures in the Chicago Area}

\begin{tabular}{|lrrrr|} 
& \multicolumn{4}{c}{ Year } \\
Agency & 1997 & 1998 & 1999 & 2000 \\
\hline City of Chicago & $5,985.4$ & $6,699.9$ & $5,257.7$ & $6,188.8$ \\
Chicago Area Transportation Study & $4,742.1$ & $5,321.0$ & $5,149.0$ & $6,483.0$ \\
Chicago Transit Authority & $1,313.2$ & $1,270.2$ & $1,938.1$ & $2,111.5$ \\
Northeastern Illinois Planning Commission & $1,415.0$ & $1,605.0$ & $1,549.4$ & $1,812.5$ \\
Metra & $1,561.0$ & $1,451.0$ & $1,337.3$ & $1,086.0$ \\
Regional Transportation Authority & 953.8 & $1,253.3$ & $1,463.3$ & $1,753.6$ \\
Pace & $1,091.4$ & 849.0 & 824.5 & $1,028.7$ \\
Regional Council of Mayors & 740.4 & 676.5 & 675.0 & 781.0 \\
Counties & 0.0 & 60.0 & 110.0 & 120.0 \\
& & & & \\
Total & $17,802.3$ & $19,186.4$ & $18,304.3$ & $21,365.1$ \\
\hline
\end{tabular}

Source: CATS (1999).

Major transportation planning expenses in the Chicago region include management, communications, and information services, as well as preparation of short- and long-range transportation plans. Additional expenses may include subregional and corridor studies, transportation system management (TSM) programs, needs assessments for special groups (e.g., the elderly, poor, minorities, and women), and environmental and energy impact studies.

CATS is the lead agency for highway planning; RTA the lead agency for transit planning; and NIPC the lead agency for land-use planning in the Chicago area. About 40 percent of the regional transportation planning budget is devoted to transit and related issues in Chicago, versus less than 20 percent nationally (CATS 1999). Chicago is one of only two metropolitan regions in the United States (the other being New York) where more than half of the commuters destined for the CBD use public transportation as their preferred mode of travel.

\section{Public Transportation}

RTA was formed in 1974 to provide suburban transit service; it was reorganized in 1983 to become a funding agency with planning responsibilities for transit in the six-county northeastern Illinois region. CTA was formed in 1945 to consolidate Chicago's public and private mass transit carriers. It has the exclusive right to operate a passenger transportation system within the City of 
Chicago. The Northeastern Illinois Regional Commuter Rail Corporation, acting under the service name Metra, was formed in 1980 to serve as RTA's commuter rail division. Pace began operating independently in 1984, and is empowered to operate bus service in suburban Cook County and the five "collar" counties of DuPage, Kane, Lake, McHenry, and Will (RTA 1999).

The Chicago area has remained relatively stable in population over the last three decades. The developed portion of the six-county metro area has grown by more than 50 percent during the same time period, however, the result of internal out-migration of the urban population to the Chicago suburbs, exurbs, and beyond. This population dispersion has negatively affected transit ridership, mainly in the central city. CTA lost 35 percent of its ridership, Metra ridership grew by 20 percent, and Pace ridership held steady between 1985 and 1997 (Table 3).

Operating subsidies were fairly stable in real terms across all three Chicago transit operators between 1985 and 1997, making a supply-side explanation for observed differences in ridership trends among them unlikely as a major contributing factor. It appears that CTA lost ridership as a result of decreasing demand for transit within the City, a direct result perhaps of significant population losses. Pace was unable to capitalize on CTA losses due to difficult market conditions for suburb-to-suburb travel. Metra experienced modest ridership gains while CTA lost more than one-third of its customers. Metra's unit operating subsidies have declined in real terms, an unusual occurrence in the contemporary U.S. transit industry (Pickrell 1983).

Dueker et al. (1998) demonstrate that parking management in the CBDs of large metropolitan regions is related to the quality of transit service provided (Figure 1). They define an index of transit service quality as a function of:

- percentage of commute trips made by transit,

- percentage of the population residing within $1 / 4$ mile (walking distance) of transit, and

- annual transit revenue hours of service per capita.

Dueker et al. (1998) identify five key types of parking management strategies: 


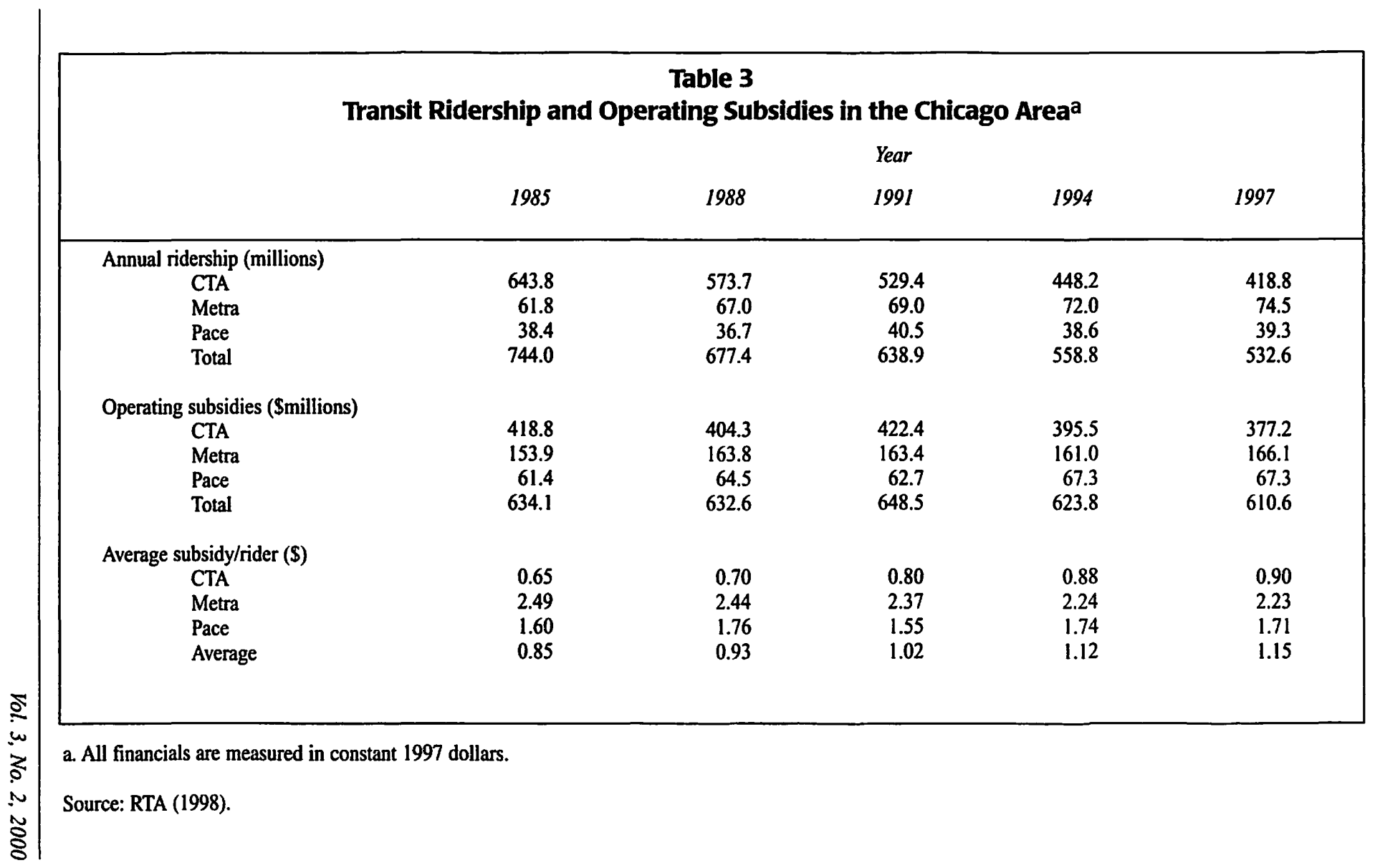


1. Parking maximums are imposed in the CBD.

2. A parking tax of more than 10 percent is levied.

3. Maximum hourly parking meter rates are higher than the sample average of $\$ 1.18$ per hour.

4. Stand-alone parking garages are not unconditionally allowed in the CBD.

5. Residential parking permit programs are actively in place.

The City of Chicago employs all of these parking management programs except the first one (Figure 1). This article provides a detailed exploration of the relationship between parking management and transit service, using commuter rail in Chicago as a case example.

\section{Parking Management}

Lee (1994) reviewed pricing strategies for RTA, including parking pricing, congestion pricing, vehicle miles of travel (VMT) or emissions fees, and increased fuel taxes. He concluded that parking pricing strategies are preferable in Chicago because:

- peak-period travel is easier to target,

- mode choice changes are more likely to occur,

- administrative and technological costs are likely to be lower,

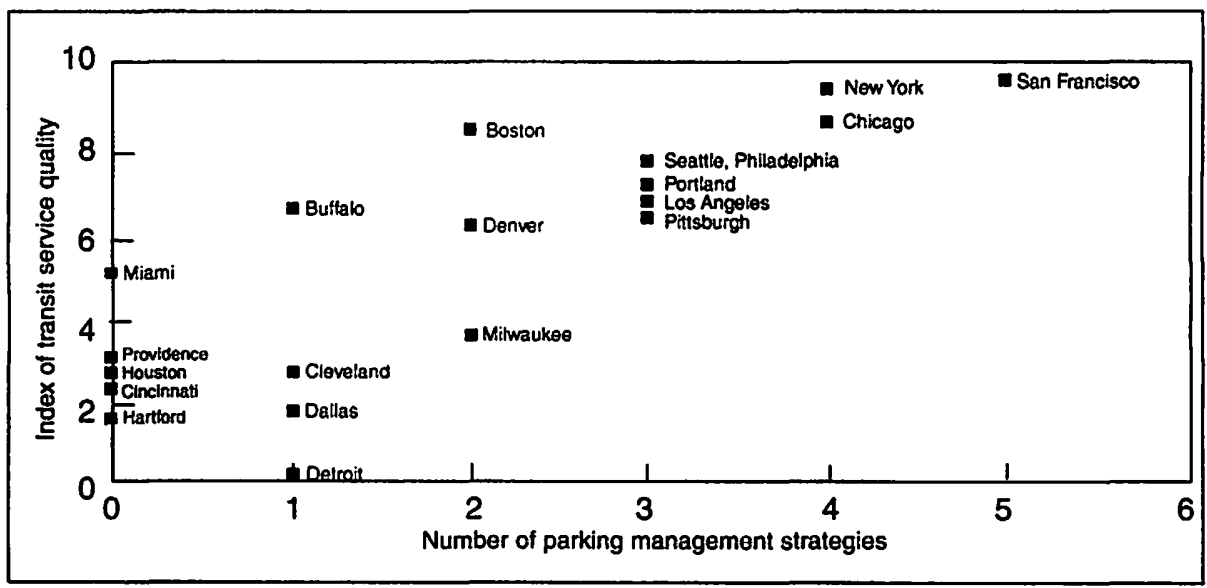

Figure 1. Parking management by transit service

Source: Dueker, Strathman, and Bianco (1998). 
- fiscal impacts are likely to be less regressive, and

- political acceptability is likely to be higher.

Market Shares (1995) surveyed a stratified sample of 1,000 employers with 100 employees or more in the Chicago area on the availability of free employee parking (Table 4). Chicago CBD employers were easy to distinguish from other employers on every count. Other Chicago employers were easily distinguishable on most counts, but were much more like suburban employers than Chicago CBD employers overall. Employers in suburban Cook County could not be distinguished from employers in the collar counties on any count.

\begin{tabular}{|c|c|c|c|c|}
\hline \multicolumn{5}{|c|}{$\begin{array}{c}\text { Table } 4 \\
\text { Employee Parking Provisions and Transit Use in the Chicago Area }\end{array}$} \\
\hline & \multicolumn{2}{|c|}{ Chicago CBD Other Chicago } & \multirow{2}{*}{$\frac{\text { Other Cook }}{4 \%}$} & \multirow{2}{*}{$\frac{\text { Collar Counties }}{2 \%}$} \\
\hline $\begin{array}{l}1990 \text { census transit mode split } \\
\text { Industry }\end{array}$ & $55 \%$ & $19 \%$ & & \\
\hline Manufacturing & $12 \%$ & $36 \%$ & $35 \%$ & $34 \%$ \\
\hline Distribution & $11 \%$ & $19 \%$ & $27 \%$ & $29 \%$ \\
\hline Services & $77 \%$ & $42 \%$ & $36 \%$ & $36 \%$ \\
\hline \multicolumn{5}{|l|}{ Employees who park free } \\
\hline All & $6 \%$ & $79 \%$ & $97 \%$ & $94 \%$ \\
\hline Some & $29 \%$ & $5 \%$ & $1 \%$ & $1 \%$ \\
\hline None & $65 \%$ & $15 \%$ & $2 \%$ & $5 \%$ \\
\hline \multicolumn{5}{|l|}{ Employer access to free parking } \\
\hline Company owned & $30 \%$ & $80 \%$ & $74 \%$ & $75 \%$ \\
\hline Included in property lease & $32 \%$ & $17 \%$ & $25 \%$ & $25 \%$ \\
\hline Separate parking lease & $38 \%$ & $3 \%$ & $1 \%$ & $0 \%$ \\
\hline Median parking cost & $\$ 160$ & $\$ 75$ & $\$ 28$ & $\$ 24$ \\
\hline \multicolumn{5}{|l|}{ Parking cost estimates } \\
\hline Don't know & $8 \%$ & $61 \%$ & $68 \%$ & $75 \%$ \\
\hline Free or minimal cost & $1 \%$ & $14 \%$ & $22 \%$ & $14 \%$ \\
\hline Cost estimate provided & $91 \%$ & $25 \%$ & $10 \%$ & $11 \%$ \\
\hline
\end{tabular}

Source: Market Shares (1995).

Most employees in the Chicago CBD were required to pay for their own parking, at a median cost of $\$ 160$ per month. It is not very hard to see why 55 percent of Chicago CBD employees chose public transit over driving alone to work. Few employers had any idea how much parking might cost them out in the suburbs, and even fewer employees were required to pay for their own parking there. 
K. T. Analytics (1995) developed a generic handbook on implementing parking management strategies for RTA. The handbook discusses each of the following strategies in terms of planning, staffing, administration, facilities, and evaluation:

- Supply strategies

-Preferential parking for carpools and vanpools

-Peripheral parking with shuttle bus connecting service

-On-street parking restrictions

-Reducing minimum parking requirements

-Instituting parking maximums

-Areawide parking caps

- Pricing strategies

-Vehicle occupancy price breaks

- Time-based pricing policies

-Parking taxes

-Elimination of employee parking subsidies

-On-street parking meters

The City of Chicago requires a rather nominal 0.1 parking spaces per 1,000 square feet of new office space, imposes a $\$ 25 /$ month parking tax, operates 7,000 parking meters, but owns only 472 of 83,887 other parking spaces available in the CBD. The City controls residential parking in high-demand areas through permit programs. More than 345 city blocks, mainly located near Lake Michigan on the north side of town, each have their own separate permit program. Suburban Chicago communities typically rely on traditional methods of requiring a surfeit of parking for all new developments in order to reduce or eliminate the incidence of spillover parking.

\section{Commuter Rail}

Metra has done well in recent years, but things have not always been so rosy for Chicago's commuter rail service provider. In the early 1980s, Metra experienced serious ridership declines similar to those suffered by CTA in the 1990s. Between 1979 and 1983, average weekday passenger boardings on Metra fell from 271,455 to 203,971-a 25 percent decline in four years. A mar- 
ket research study undertaken by Metra in 1985 identified lack of parking at suburban rail stations as the single largest factor contributing to observed ridership losses (Parking Implementation Committee [PIC] 1995).

As a result of this study, Metra formed a standing PIC, and charged it with planning a major expansion of parking opportunities for Metra customers at commuter rail stations throughout the system. Between 1988 and 1995, the PIC completed 139 parking projects, added 17,267 new spaces, and improved 7,005 existing spaces for a total of 24,272 new or improved parking spaces. Parking capacity at Metra stations grew from 54,121 in 1986 to 68,301 in 1994, an increase of 14,180 , or 26 percent (Table 5). The net gain in parking capacity was slightly less than the total of new spaces added, mainly due to attrition. Parking management at light rail stations has been studied (Dickens 1991), but not at commuter rail stations.

Observed Metra station parking use increased from 46,997 in 1986 to 58,882 in 1994 , an increase of 11,885 . This 25 percent increase in station park-

\begin{tabular}{|c|c|c|c|c|c|}
\hline \multicolumn{6}{|c|}{$\begin{array}{c}\text { Table } 5 \\
\text { Commuter Rail Ridership, Parking Capacity, and Observed Use }\end{array}$} \\
\hline & \multicolumn{5}{|c|}{ Distance to $C B D$} \\
\hline & $0-10$ & $10-20$ & $20-30$ & $30+$ & System \\
\hline \multicolumn{6}{|c|}{ Weekday boardings (AM peak inbound) } \\
\hline 1986 & 6,250 & 40,574 & 42,000 & 9,800 & 98,624 \\
\hline 1994 & 7,938 & 44,226 & 46,494 & 14,742 & 113,399 \\
\hline Change 1986-94 & 1,688 & 3,652 & 4,494 & 4,942 & 14,775 \\
\hline Change 1986-94 & $27 \%$ & $9 \%$ & $11 \%$ & $50 \%$ & $15 \%$ \\
\hline \multicolumn{6}{|l|}{ Station parking capacity } \\
\hline 1986 & 2,918 & 20,676 & 22,591 & 7,936 & 54,121 \\
\hline 1994 & 3,824 & 24,047 & 28,134 & 12,296 & 68,301 \\
\hline Change 1986-94 & 906 & 3,371 & 5,543 & 4,360 & 14,180 \\
\hline Change 1986-94 & $31 \%$ & $16 \%$ & $25 \%$ & $55 \%$ & $26 \%$ \\
\hline \multicolumn{6}{|c|}{ Station parking use (observed) } \\
\hline 1986 & 2,493 & 17,937 & 20,029 & 6,538 & 46,997 \\
\hline 1994 & 3,079 & 19,647 & 25,631 & 10,525 & 58,882 \\
\hline Change 1986-94 & 586 & 1,710 & 5,602 & 3,987 & 11,885 \\
\hline Change 1986-94 & $24 \%$ & $10 \%$ & $28 \%$ & $61 \%$ & $25 \%$ \\
\hline \multicolumn{6}{|c|}{ Average parking occupancy (percent) } \\
\hline 1986 & $85 \%$ & $87 \%$ & $89 \%$ & $82 \%$ & $87 \%$ \\
\hline 1994 & $81 \%$ & $82 \%$ & $91 \%$ & $86 \%$ & $86 \%$ \\
\hline
\end{tabular}

Source: Metra (unpublished data). 
ing use, while matching the net increase in parking capacity almost exactly, greatly exceeded the 15 percent increase in Metra ridership observed during the same time period. This suggests that more people were driving to Metra rail stations rather than walking or taking transit, with potentially serious air quality implications.

\section{Station Access and Air Quality}

Access to Metra rail stations is identified through customer surveys conducted on a rotating basis to ensure that access data for no station are older than about five years, with an average of about two years. For the Metra system as a whole, just over half (55\%) of all inbound AM peak commuters drive alone to their preferred rail station. Driving alone increases in significance, walking decreases rapidly, and all other station access modes are relatively insensitive to distance from the Chicago CBD (Table 6).

\begin{tabular}{|c|c|c|c|c|c|}
\hline Commute & $\begin{array}{l}\text { Tabl } \\
\text { Acces }\end{array}$ & nd Pre & cted P & king U & \\
\hline & & & ance to $\mathrm{C}$ & & \\
\hline & $0-10$ & $10-20$ & $20-30$ & $30+$ & System \\
\hline Mode of station access & & & & & \\
\hline Drove alone & $25 \%$ & $43 \%$ & $61 \%$ & $71 \%$ & $55 \%$ \\
\hline Walked & $59 \%$ & $34 \%$ & $12 \%$ & $6 \%$ & $21 \%$ \\
\hline Dropped off & $10 \%$ & $13 \%$ & $14 \%$ & $14 \%$ & $13 \%$ \\
\hline Carpool & $3 \%$ & $5 \%$ & $6 \%$ & $6 \%$ & $6 \%$ \\
\hline Took bus & $2 \%$ & $4 \%$ & $5 \%$ & $2 \%$ & $4 \%$ \\
\hline Other & $1 \%$ & $1 \%$ & $1 \%$ & $1 \%$ & $1 \%$ \\
\hline Station parking use ( $\mathrm{p}$ & & & & & \\
\hline 1986 & 1,681 & 18,380 & 26,964 & 7,232 & 54,703 \\
\hline 1994 & 2,135 & 20,034 & 29,849 & 10,880 & 62,898 \\
\hline Change 1986-94 & 454 & 1,654 & 2,885 & 3,648 & 8,195 \\
\hline Change 1986-94 & $27 \%$ & $9 \%$ & $11 \%$ & $50 \%$ & $15 \%$ \\
\hline Station parking use (pr & & & & & \\
\hline 1986 & $(812)$ & 443 & 6,935 & 694 & 7,706 \\
\hline 1994 & (944) & 387 & 4,218 & 355 & 4,016 \\
\hline Change 1986-94 & (132) & $(56)$ & $(2,717)$ & (339) & $(3,690)$ \\
\hline Change 1986-94 & $16 \%$ & $-13 \%$ & $-39 \%$ & $-49 \%$ & $-48 \%$ \\
\hline
\end{tabular}

Source: Metra (unpublished data). 
A commuter who normally drives alone to work who instead drives to a rail station and then commutes the old-fashioned way, on a train, will reduce the quantity of air pollution he or she puts into the air. However, a commuter who normally walks to a rail station who instead drives there will increase the quantity of air pollution he or she produces. Thus, depending on their prior mode of access, Metra commuters could be treated as either air polluters or clean air contributors (Marchwinski and Fittante 1993).

Meridian (1994) surveyed Metra riders and found, much to their astonishment, that there were virtually no cases of individuals switching from walking to driving alone to access Metra rail stations. Metra ridership increased most rapidly at stations less than 10 miles and more than 30 miles from the Chicago CBD (Table 5). These results strongly suggest that out-migration cannot explain higher than expected increases in station parking use. Out-migration in this context includes both those who move farther away from the CBD and use Metra rail stations farther out, as well as those who travel farther to reach Metra rail stations, whether or not they move farther away from the CBD.

Given mode of access data, it is possible to predict parking use at Metra stations by Metra commuters (Ferguson 2000). Predicted parking use should be identical to, or at least roughly comparable with, actual observed use. This is only true, however, if (1) all Metra users who drive to Metra stations park in Metra parking lots, and (2) no one who does not use Metra chooses to park there. These conditions are not met. It appears instead that Metra parking use less than 10 miles from the CBD includes a significant portion of non-Metra users, while farther out, there are more Metra users who drive to Metra stations than there are Metra parking spaces being filled by anyone. In fact, at stations 20 to 30 miles from the CBD, there are more Metra drivers than there are Metra parking spaces, including even those spaces that are not occupied during the peak period (Table 6).

Metra charges an average of about $\$ 1$ per day to park in Metra parking lots (Table 7). Most Metra parking lots within 10 miles of the CBD are free, by prior agreement with the City of Chicago. Some Metra parking lots, by agreement with local authorities or private owners, limit access to residents only, or offer lower parking fees to residents. These discriminatory practices are dis- 


\section{Table 7}

\section{Commuter Rail Parking Pricing}

\begin{tabular}{lrrrrr} 
& \multicolumn{5}{c}{ Distance to CBD } \\
& $0-10$ & $10-20$ & $20-30$ & $30+$ & System \\
\cline { 2 - 6 } & & & & & \\
Pricing policy (percent of parking lots) & $75 \%$ & $32 \%$ & $2 \%$ & $19 \%$ & $27 \%$ \\
$\quad$ Free & $0 \%$ & $3 \%$ & $6 \%$ & $3 \%$ & $3 \%$ \\
$\quad$ Resident only & $22 \%$ & $52 \%$ & $77 \%$ & $78 \%$ & $59 \%$ \\
$\quad$ Uniform pricing & $3 \%$ & $13 \%$ & $15 \%$ & $1 \%$ & $11 \%$ \\
$\quad$ Discriminatory pricing & & & & & \\
Average equivalent daily parking price & $\mathrm{n} / \mathrm{a}$ & $\$ 0.55$ & $\$ 0.76$ & $\$ 0.90$ & $\$ 0.69$ \\
$\quad$ Resident only & $\$ 1.07$ & $\$ 1.06$ & $\$ 1.07$ & $\$ 0.96$ & $\$ 1.00$ \\
$\quad$ Uniform pricing & $\$ 0.48$ & $\$ 0.63$ & $\$ 0.75$ & $\$ 0.48$ & $\$ 0.65$ \\
$\quad$ Discriminatory-residents & $\$ 0.95$ & $\$ 1.07$ & $\$ 1.15$ & $\$ 0.71$ & $\$ 1.06$ \\
$\quad$ Discriminatory-nonresidents & $4 \%$ & $33 \%$ & $30 \%$ & $19 \%$ & $24 \%$ \\
Permit required in order to park & & & & & \\
\end{tabular}

Source: Metra (unpublished data).

couraged by Metra to the greatest extent possible for pragmatic reasons.

Within 10 miles of the CBD, fully 75 percent of Metra parking lots are available free of charge to the public. It is no surprise to discover that nonMetra users may choose to park in unrestricted Metra parking lots from time to time, particularly when one considers the relative cost of non-Metra parking in the City of Chicago. More than 10 miles from the $\mathrm{CBD}$, parking spaces other than those at Metra rail stations are the ones that are most likely to be provided free of charge (Table 4). It is again no surprise to find that some Metra riders may prefer not to pay a buck for parking, even if it means enduring the not inconsiderable inconvenience of walking a bit further out of one's way in order to get from that nominally free parking space to the main station entrance.

In their defense, Metra's parking program seems to have significantly reduced the number of Metra users who choose to park off-site at suburban commuter rail stations. The net difference between the number of people who claim to drive and park near Metra stations and the number of Metra parking spaces occupied during peak-travel periods has fallen from 7,706 in 1986 to 4,016 in 1994, a 48 percent decrease (Table 6). Metra may not have eliminated spillover parking from its suburban station areas entirely, but a significant dent in the problem has been made.

The observed difference between Metra ridership and parking trends is 
best explained, not as the result of changes in mode of station access, but rather in terms of the location chosen to park one's car once one is within the immediate vicinity of the station. Ferguson (1999) demonstrates that the price elasticity of demand for off-site parking is four to five times as great as that for alternative modes of travel with respect to on-site parking prices. This implies that parking location is much more elastic than mode of travel as a variable factor in travel decisions, especially those related to commuting. Solo drivers in Atlanta park off-site to save $\$ 1$ to $\$ 2$ per day in parking charges, rather than switching to alternative modes. The same phenomenon would seem to apply in the case of auto access to commuter rail stations in the Chicago area.

\section{Reverse Commuting and Social Equity}

About 90 percent of Metra ridership occurs during peak weekday travel periods, and is not bidirectional. Most Metra riders get up in the morning, catch the train out in the suburbs, head into the city, get off at 1 of the 11 terminals scattered around the Chicago CBD, walk to work, and later head back to the suburbs at the end of another working day. This classic commuting pattern is not just a relic of a bygone era, but the actual demand profile for almost 90 percent of Metra's commuter rail patrons today.

A small percentage of Metra's ridership base is composed of reverse commuters, people who live either in or near the City of Chicago, and who travel outward from the CBD in the morning to reach their suburban jobs, returning inbound in the evening to their urban dwellings. Reverse commuting was a hot topic of debate in the early 1990s (Farkas 1992). Proussaloglou and Koppelman (1989) developed an attitudinal approach to market research specific to commuter rail service, using Metra as an example. Total Research (1991) applied this technique to a sample drawn from Metra's reverse commuters.

Reverse commuters were asked to rate nine key Metra service attributes in terms of (1) its importance to them as a consumer, and (2) Metra's performance as a service provider in that regard (Figure 2). Speed was determined to be the median service attribute of Metra rail service. Relative to speed, there were four service attributes whose performance exceeded consumer expectations, and four whose performance lagged expectations. Staff courtesy 


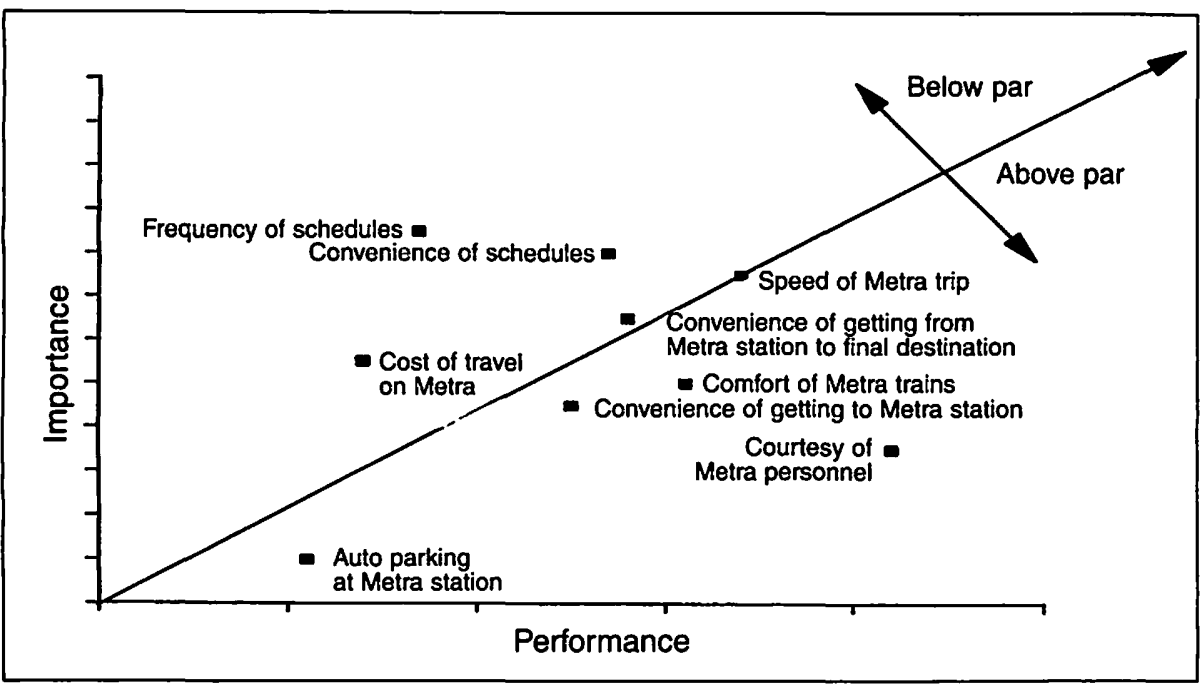

Figure 2. Key service attributes of commuter rail for reverse commuters

Source: Total Research (1991).

received the highest rating of any Metra service attribute on performance, but was rated second lowest in terms of importance to the consumer. Schedule frequency ranked the highest in terms of importance to the consumer, but got the third lowest rating in actual performance.

Availability of auto parking at Metra stations scored the lowest in terms of both its importance to the consumer and Metra's actual performance vis-à-vis reverse commuting. Almost half $(44 \%)$ of all Metra reverse commuters board the train at one of the downtown terminals, which have no parking at all. Another third (36\%) board the train within 10 miles of the CBD, where parking availability is minimal and auto access to Metra stations is quite low as well (Table 6). Given the fiscal realities of the situation (Tables 1, 2, and 3), neither reducing Metra fares nor increasing the frequency or convenience of schedules for reverse commuters was feasible at that time. However, the convenience of getting from Metra stations to one's final work destination seemed like an addressable issue, without too much added cost or disruption to existing service, even if it was rated only slightly below par (Figure 2). 
The TMA of Lake-Cook proposed a shuttle service linking a new commuter rail station on the Metra-Milwaukee District North Line with almost 30,000 employees located within 0.5 mile on either side of Lake-Cook Road in a corridor slightly more than 5 miles long (Fish, Dock, and Baltutis 1995). A survey of employees in the Deerfield-Northbrook area revealed that 25 percent lived within the general confines of the commuter rail corridor, and might potentially use Metra in order to get to work. Although 60 percent of the population to be served by the proposed shuttle were reverse commuters, the project was termed a "suburb-to-suburb" demonstration. Significant pedestrian improvements linking Metra to employers within a 0.5 mile radius of the rail station were included in this project.

Reverse commuting and social equity figure into the parking management equation in two different ways. Every dollar spent on parking for suburban commuters is a dollar that cannot be spent on commuter rail operations. Parking is far more important for station access in the distant suburbs than it is for reverse commuters, especially those whose trips begin in the City of Chicago itself. Although this conflict may be more apparent than real in economic terms, it can be quite important politically, and should not be discounted entirely as a result.

\section{Land Use and Urban Form}

Higher than expected increases in parking lot utilization at Metra rail stations appear to be the result of changes in parking location rather than mode of station access. This suggests that spillover parking has fallen without negatively affecting regional air quality. Auto access to Metra increases with distance to the CBD. This means that Metra users will become more reliant on automobiles in the future, given current trends in urban development. Auto access to commuter rail must necessarily increase as the population of northeastern Illinois continues its outward migration within the ever-expanding confines of the greater Chicago metropolitan region.

The only realistic alternative is for land use around exurban Metra commuter rail stations to change as well (Cervero 1995; Cervero and Landis 1993). Metra, working in conjunction with NIPC, has developed a set of policy guidelines for use by local communities in planning for development around com- 
muter rail stations in order to encourage increased use of commuter rail, and promote commuter rail station access by modes of transportation other than the single occupant automobile (NIPC 1996).

Metra and NIPC have identified six typical station area land-use patterns for use in illustrating the basic principles of pedestrian-friendly urban design. These include one urban pattern (typical of the City of Chicago), three suburban patterns (typical of fully developed inner suburbs), and two exurban patterns (typical of outlying areas in the midst of the earliest throes of urban development). (See Table 8.)

These prototypical land-use patterns illustrate the importance of convenient retail and services and the contribution of parking to station area development. In addition, these land-use prototypes suggest the urgent necessity of mixing land uses in order to achieve the desired result. All six patterns include at least one element of every major land-use category within a radius of 1 mile, the ancient standard of what used to constitute a comfortable walking distance. In rank order, the convenience retail services most desired by Chicago commuter rail users include: dry cleaners, restaurants, automatic tellers, grocers, coffee stands, newsstands, banks, gas stations, fast food restaurants, drug stores, convenience stores, video stores, card and gift shops, auto repair shops, hardware stores, barbers and beauty shops, bakeries and donut shops, day care centers, florists, and last and probably least, book stores (Camiros 1996). Of these convenience services, only child care has been studied in conjunction with commuter rail previously (Pansing et al. 1992).

Metra developed a shared parking program beginning in 1992. The program was designed to provide additional parking in station areas where supply is limited and additions would be cost prohibitive, and promote joint marketing of Metra commuter rail service in conjunction with participating organizations. Almost 3,000 shared spaces were added to the Metra system between 1992 and 1995 (Table 9), roughly in proportion to preexisting parking capacity and utilization (Table 5). Commercial joint parking partners covered a wide range of activities from race tracks and shopping centers to gas stations, body shops, and beauty salons. Most of the fraternal organizations were churches of various denominations. 


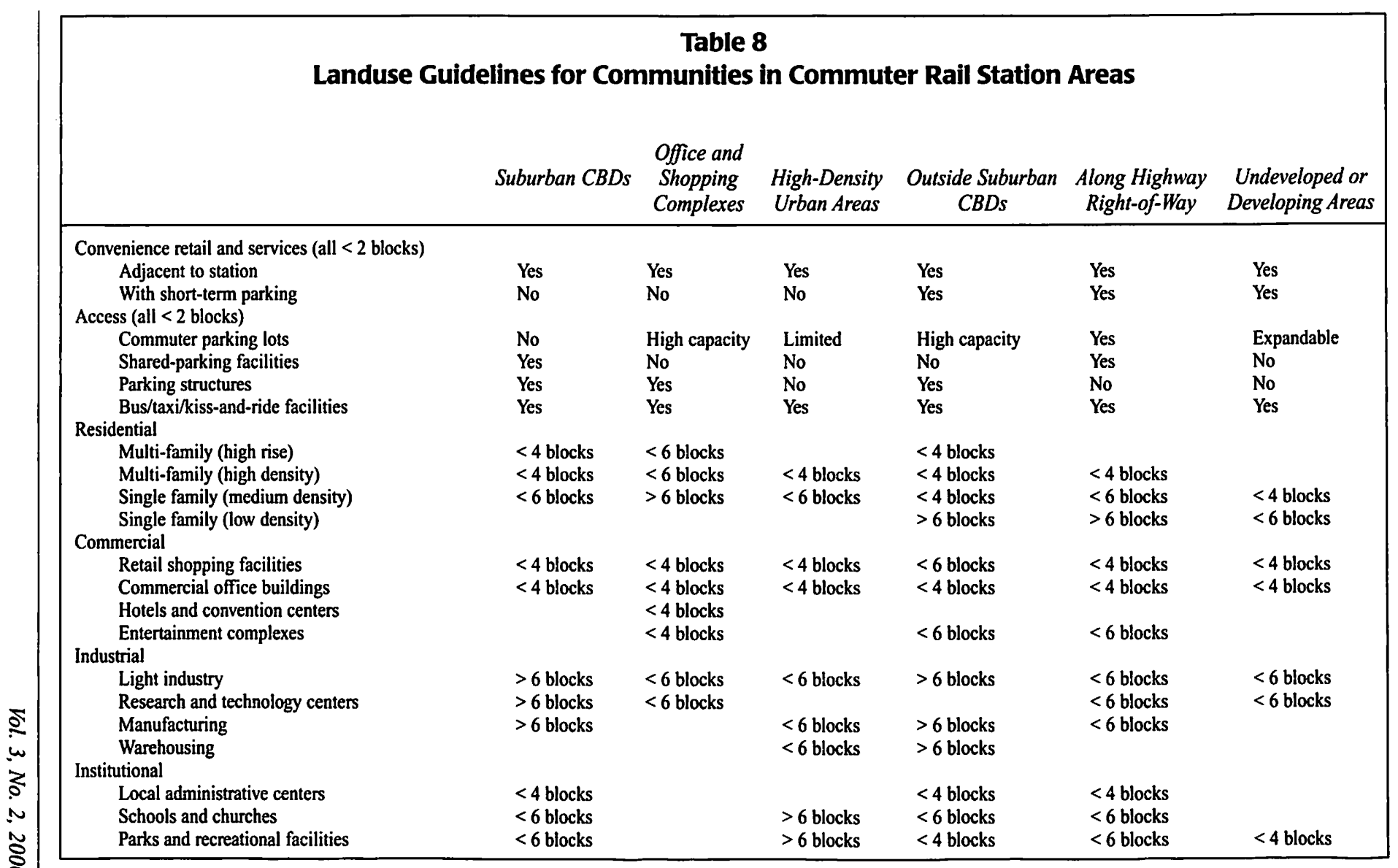




\section{Table 9}

\section{Commuter Rail Shared Parking}

Joint users (number of lots)

Commercial

Fraternal

Other

Total shared parking lots

Total shared parking spaces

Average parking spaces/lot

\begin{tabular}{rrrrr}
\multicolumn{5}{c}{ Distance to CBD } \\
$0-10$ & $10-20$ & $20-30$ & $30+$ & System \\
\hline & 5 & 16 & 1 & 24 \\
2 & 10 & 3 & 1 & 15 \\
2 & 2 & 3 & 3 & 10 \\
6 & 17 & 22 & 5 & 50 \\
383 & 887 & 1,111 & 427 & 2,808 \\
64 & 52 & 51 & 85 & 56
\end{tabular}

Source: PIC (1995).

Parking may be a major element in the transportation system, but it is also an important form of land use. In fact, surface parking often covers far more land than the "other" land uses it is intended to serve. Where automobile access is critical to success, as seems to be the case for suburban commuter rail stations, the demand for parking and associated pricing policies cannot be separated from an overall view of the complex integrative function that it serves. Spillover parking may be desirable where shared parking opportunities exist, but is undesirable where adjacent land uses will be adversely affected. Commuter rail parking is best understood in the context of both transportation and land-use planning and development as a result.

\section{Conclusions}

Parking in and around Metra's commuter rail stations is sensitive to changes in parking supply and pricing policies. Mode of access to Metra commuter rail stations is far less sensitive to parking pricing than it is to distance from the CBD, this being a reasonable proxy for distance to the station, itself a function of density of development and urban form. The implications of these findings from a policy perspective can be summarized as follows:

- Restricted parking in and around commuter rail stations must inevitably lead to lower commuter rail ridership, unless:

- significant improvements in station access via other modes can be provided;

—shared parking is made available; and/or

-spillover parking is tolerated. 
- Higher parking prices at commuter rail stations must inevitably lead to increased spillover parking, unless:

-station access via other modes is improved;

-station parking amenities are improved (relevant examples might include covered parking, convenience retail, and/or enhanced security protection); and/or

- prices at adjacent parking facilities increase in tandem with station parking prices.

- Commuter rail stations experience peak-parking demands during extremely well-defined time periods-namely, weekdays during normal working hours-plus a generous allowance on either side for time spent commuting. This creates an excellent opportunity for shared parking, under appropriate conditions:

-Fraternal organizations, such as religious institutions, exhibit the opposite demand profile, with parking required mainly during the evening and on weekends.

- Commercial establishments may benefit from market opportunities generated by shared parking with commuter rail stations and their patrons.

- Local government enterprises, such as recreational facilities, may also benefit from shared parking with commuter rail stations.

Metra should be applauded for its efforts to recognize the complex problems associated with commuter rail station access and associated parking facilities. Other transit service providers struggling with similar problems, especially along new light or commuter rail lines, may benefit from this example of what to do, and what not to do.

\section{Acknowledgments}

This research was funded by the Transit Cooperative Research Program of the Transportation Research Board of the National Research Council of the National Academies of Science and Engineering. The author would like to thank Ken Dueker of Portland State, Reed Lee of RTA, Gary Foyle of Metra, Claudine Lucier of CATS, Bill Baltutis of the TMA of Lake-Cook, and two anonymous reviewers for their thoughtful and timely assistance. 


\section{References}

Black, Alan. 1990. The Chicago area transportation study: A case study of rational planning. Journal of Planning Education and Research 10: 27-37.

Camiros. 1996. Local economic benefits of commuter rail stations for communities and businesses. Chicago, IL: Metra.

Cervero, Robert. 1995. Commuting in transit versus automobile neighborhoods. Journal of the American Planning Association 62: 492-511.

Cervero, Robert, and John Landis. 1993. Assessing the impacts of urban rail transit on local real estate markets using quasi-experimental techniques.

Transportation Research 27A: 13-22.

Chicago Area Transportation Study (CATS). 1999. Unified work program for transportation, Northeastern Illinois, FY 2000. Chicago, IL: Chicago Area Transportation Study.

Dickens, Ian S. J. 1991. Park-and ride-facilities on light rail transit systems. Transportation 18: 23-36.

Dueker, Kenneth J., James G. Strathman, and Martha J. Bianco. 1998.

Strategies to attract auto users to public transportation. TCRP Report 40. Washington, DC: Transportation Research Board.

Farkas, Z. Andrew. 1992. Reverse commuting: Prospects for job accessibility and energy conservation. Transportation Research Record 1349: 85-92.

Ferguson, E. 1999. Office development, parking management, and travel behavior: The case of midtown Atlanta. Journal of Transportation and Statistics 2: 93-107.

Ferguson, E. 2000. Travel demand management and public policy. London: Ashgate.

Fish, Cindy A., Frederick C. Dock, and William J. Baltutis. 1995. Lake-Cook corridor suburb-to-suburb commuter demonstration project. Transportation Research Record 1496: 158-167.

Gray, George E. 1992. Statistical summary of operating North American commuter rail services. Transportation Research Record 1349: 62-65. 
K. T. Analytics. 1995. Parking management strategies: A handbook for implementation. Chicago, IL: Regional Transportation Authority.

Lee, Reed. 1994. An assessment of travel pricing strategies. Chicago, IL: Regional Transportation Authority.

Marchwinski, Thomas W., and Steven R. Fittante. 1993. Air quality and costrevenue impacts of connector bus services for commuter rail. Transportation Quarterly 47: 295-310.

Market Shares. 1995. Availability of free employee parking at employers and worksites with 100 or more employees in the Chicago area. Chicago, IL: Regional Transportation Authority.

Meridian. 1994. Financial and air quality analysis of commuter rail parking facilities. Chicago, IL: Metra.

Metra. 1994. Preliminary 1995 program and budget. Chicago, IL.

Northeastern Illinois Planning Commission (NIPC). 1996. Land use in commuter rail stations: Guidelines for communities. Chicago, IL: Metra.

Pansing, Cynthia, Phyllis Stewart-Pires, and Stuart Anderson. 1992. Feasibility study for providing child care at San Fernando Valley commuter rail stations. Transportation Research Record 1349: 66-72.

Parking Implementation Committee (PIC). 1995. 1996 parking program. Chicago, IL: Metra.

Pickrell, Don H. 1983. The causes of rising transit operating deficits. Washington, DC: U.S. Department of Transportation.

Proussaloglou, Kimon E., and Frank S. Koppelman. 1989. Use of travelers' attitudes in rail service design. Transportation Research Record 1221: 42-50.

Regional Transportation Authority (RTA). 1999. 1998 annual report. Chicago, IL.

Total Research. 1991. A study of reverse commuters in the Chicago metropolitan area. Chicago, IL: Regional Transportation Authority. 


\section{About the Author}

ERIK FERGuSON (etferg@mindspring.com) is principal of ETF Associates in Atlanta and the author of a recent textbook on travel demand management and public policy. 